\title{
Low-Level Jets in the Moscow Region in Summer and Winter Observed with a Sodar Network
}

\author{
Margarita A. Kallistratova • Rostislav D. Kouznetsov
}

Received: 19 October 2010 / Accepted: 14 July 2011 / Published online: 4 August 2011

(C) Springer Science+Business Media B.V. 2011

\begin{abstract}
We evaluate the statistical properties of low-level jets (LLJs) observed by means of a network of Doppler sodars in the Moscow region, Russia. Continuous long-term measurements of the echo-signal intensity and wind-velocity profiles were carried out in July 2005 and in 2008-2010 synchronously in the centre of Moscow and at a rural site. The summertime nocturnal LLJs have a very clear diurnal cycle and exhibit features predicted by the Blackadar mechanism. In contrast, the long-lasting wintertime jets do not have any clear diurnal variability. The urban environment strongly influences LLJs in both seasons: above the city LLJs are higher, weaker and observed more rarely than at the rural site. In very cold periods (air temperature below $-8^{\circ} \mathrm{C}$ ) no LLJs were observed over the city, instead convection emerged in the urban boundary layer. The results are based on observations made in July 2005, January and December 2009, and January 2011.
\end{abstract}

Keywords Low-level jets · Sodar · Urban Boundary Layer

\section{Introduction}

The low-level jet (LLJ) is a mesoscale flow phenomenon that appears in a stably-stratified atmospheric boundary layer (ABL). The LLJ is characterized by a sharp maximum in the wind-speed profile within hundreds of metres above the surface. LLJs have small vertical extent (about tens to hundreds metres), but their horizontal extent can exceed hundreds of

M. A. Kallistratova · R. D. Kouznetsov

A.M. Obukhov Institute of Atmospheric Physics, Pyzhevskii per. 3, Moscow, Russia 119451

M. A. Kallistratova

e-mail: margo@ifaran.ru

R. D. Kouznetsov $(\varangle)$

Finnish Meteorological Institute, P.O. Box 503, 00101 Helsinki, Finland

e-mail: roux@ifaran.ru 
kilometres. The studies of LLJs are important for understanding the structure and dynamics of a stably-stratified ABL, and for many practical applications as well.

Experimental studies of LLJs have been reported extensively (see e.g. Bonner 1968; Garratt 1982; Brook 1985; Kraus et al. 1985; Parish et al. 1988; Lettau 1990; Sjostedt et al. 1990; Beyrich 1994; Mitchell et al. 1995; Whiteman et al. 1997; Banta et al. 2002; Song et al. 2005; Baas et al. 2009; Karipot et al. 2009), however, up to now there is no commonly accepted criterion for identifying the LLJ, since such flows can be of different origins (such as breezes, mountain-valley circulation, synoptic baroclinity, atmospheric fronts etc.) and behave differently. In this study we focus on the LLJs that appear regularly in the stable ABL over a flat homogeneous terrain. Such LLJs are not usually seen in the regional climatological wind-speed profiles due to high variability in the shape and the parameters of the LLJ wind profile.

The maximum speed $V_{\max }$ and height $Z_{\max }$ of the jet core vary during a night and from day to day. This variability results in relatively smooth monthly-averaged profiles. However, if the profiles are scaled to the mean height of the jet core before averaging, the jet clearly appears in the average profile. The wind-speed profile averaged in such a way is an important climatological characteristic of a region, since the presence of a jet in the ABL influences the heat and mass exchange, short-range transport and dispersion of admixtures. Jet-type profiles are also of importance for wind-energy and flight-safety applications.

The observations of LLJs have been underway for more than half a century in many countries using tall masts, free and tethered balloons, kites and aircraft. Most of the reported observations of LLJs were carried out over the US Great Plains (Parish et al. 1988; Whiteman et al. 1997; Karipot et al. 2009), over the Australian plains (Garratt 1985; Brook 1985), and in northern Europe (Kraus et al. 1985; van Ulden and Wieringa 1996; Baas et al. 2009). In the last few decades, the appearance of new ground-based remote sensing techniques have started a new age in LLJ studies. The LLJs were studied remotely with Doppler sodars (Coulter 1981; Beyrich 1994; Emeis et al. 2007; Kallistratova et al. 2009), radars (Zhong et al. 1996; Song et al. 2005), and lidars (Banta et al. 2002; Wang et al. 2007; Banta 2008).

Most of the published experimental studies on LLJs consider LLJs that emerge during summer nights in mid-latitudes. The experimental studies of LLJs that accompany long-lived wintertime inversions over snow-covered surfaces are few. The LLJs over snow surfaces were studied in the Antarctic (Andreas et al. 2000; Anderson 2003; King et al. 2008) and in the Arctic (Vihma and Brümmer 2002; Brümmer and Thiemann 2002; Vihma et al. 2005). The main parameters of LLJs obtained in the latter studies are similar to those of nocturnal summertime LLJs. However, we have found only one study (Andreas et al. 2000), where the statistical data on LLJs over snow-covered surface are given. The measurements over the Arctic are few since they were performed by means of aircraft. The long-lived inversions appear quite often in winter over most of the Russian territory (see e.g. Serreze et al. 1992). The studies of wintertime jet flows are of importance also for Canada and Nordic countries where the snow cover is long-lasting (Henderson and Leathers 2010).

More than half-century ago Blackadar (1957) proposed a physical hypothesis on the origin of super-geostrophic nocturnal jet flows. His theory of the LLJ is based on the inertial oscillation due to the Coriolis force, after the decoupling of the flow from the surface friction, when turbulence decays in the evening. The wind velocity $\mathbf{V}$ in an atmospheric layer during the daytime is assumed to provide the Coriolis force that compensates the pressure gradient and frictional forces. After the vanishing of surface friction, the velocity in the layer starts to oscillate around the new equilibrium state given by the geostrophic velocity $\mathbf{V}_{\mathrm{g}}$, so the vector $\mathbf{W}(t)=\mathbf{V}_{\mathrm{g}}-\mathbf{V}(t)$ turns at the rate given by the Coriolis parameter. These oscillations result in super-geostrophic speeds after some time (Fig. 1). 
Fig. 1 The inertial oscillation of the wind vector around the geostrophic wind

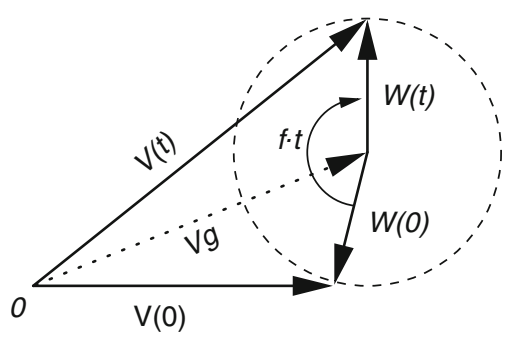

The Blackadar mechanism with some modifications is considered in many studies (see e.g. Baas et al. 2009; Van de Wiel et al. 2010; Shapiro and Fedorovich 2010). It is not yet clear, however, if the inertial oscillations are significant for the LLJ appearance in the longlived temperature inversions over snow-covered surfaces, when diurnal changes in the ABL thermal stratification are small.

Studies of LLJs over an urban area have began relatively recently. In most of such studies (see e.g. Verghese et al. 2003; Frehlich et al. 2006; Wang et al. 2007) only selected examples of wind-speed and turbulence profiles within the jet streams over some cities (e.g. Philadelphia, Washington, Oklahoma City) are considered. Note, that these studies do not have comparisons of synchronous urban and rural observations, so it is not clear if the profiles are relevant to the urban environment or to the whole region. The synchronous ABL characteristics in urban and rural environments were studied in Rome (Mastrantonio et al. 1994).

Until recently, there were no dedicated studies of LLJs in Russia, though LLJs were observed in the 1980s at a 300-m meteorological mast in Obninsk (Byzova 1982), and during studies of the ABL with Doppler sodars (Kallistratova et al. 1985, 1987; Tsvang et al. 1985; Kallistratova 1994).

In the present study we summarize the average parameters of LLJs observed by means of Doppler sodars in summer 2005 and in winter 2009-2010 over the Moscow city centre and over a rural area nearby. This study has a threefold aim:

- to examine the Blackadar mechanism for the formation of summertime and wintertime LLJs;

- to compare the parameters of LLJs and ABL stratification observed synchronously in urban and rural areas;

- to compare the statistical data on the mean parameters of urban and rural LLJs in both seasons.

The data used for our study were obtained with monostatic Doppler sodars. Sodar has certain advantages over other ground-based remote sensing for high-resolution measurements of the wind-speed profile within shallow inversion layers in the ABL (Coulter and Kallistratova 1999). Sodars are relatively inexpensive, have simple data processing routines and are suitable for a continuous long-term operation. Moreover, sodars provide the visualization of the vertical structure of the thermal turbulence within the ABL and allow for determination of several parameters of turbulence. The drawback of sodars is their low height range, which is often limited by the inversion height, preventing it from depicting the upper part of an LLJ.

The results given herein are based on a limited selected set of data obtained during one summer month and three winter months. The statistical analysis of LLJ properties for winter and summer is based on two 30-day datasets. Section 2 contains the description of the measuring sites, equipment used, and data processing. In Sect. 3 we compare the predictions of the Blackadar theory to the properties of nocturnal LLJs observed in a rural area, while 


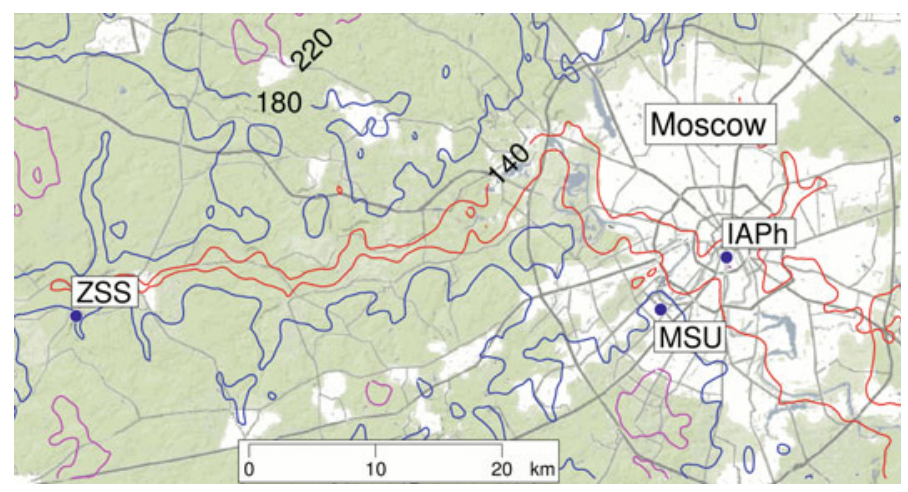

Fig. 2 The sodar measurement sites in the Moscow region. Built-up areas are marked in white

in Sect. 4 we show the difference of urban and rural nocturnal LLJs. Then we describe the long-lived wintertime LLJs in the rural and in the urban areas (Sect. 5), and demonstrate the connection between LLJ occurrence and the thermal stratification of an urban ABL (Sect. 6). The statistical parameters of LLJs in winter and in summer above urban and rural areas are given in Sect. 7, with conclusions summarized in Sect. 8.

\section{Measurement Sites, Equipment and Data Processing}

Vertical profiles of the wind speed were measured by sodars synchronously at three sites in the Moscow region. The region is mostly flat, with some small $20-80 \mathrm{~m}$ hills, and the mean elevation is about $150 \mathrm{~m}$ above ground. The region has a temperate continental climate with warm summers and long cold winters; typical air temperatures in the summer are around $20^{\circ} \mathrm{C}$, winter temperatures normally fall to approximately $-10^{\circ} \mathrm{C}$, though there are periods with daytime temperatures below $-25^{\circ} \mathrm{C}$. Snow cover lasts $3-5$ months a year. Moscow has about $11 \times 10^{6}$ inhabitants, covers over $1000 \mathrm{~km}^{2}$ area, and has an annual energy consumption of about 400 TJ (Myagkov 2004).

The locations of the measurement sites are shown in Fig. 2. The site IAPh $\left(55.73^{\circ} \mathrm{N}\right.$, $37.62^{\circ} \mathrm{E}$ ) is located at the Obukhov Institute of Atmospheric Physics (IAPh), in the central part of the city. The site $\mathrm{MSU}\left(55.70^{\circ} \mathrm{N}, 37.53^{\circ} \mathrm{E}\right)$ is at the Physical Department of Moscow State University, in the south-western part of the city, and the rural measuring site ZSS $\left(55.70^{\circ} \mathrm{N}, 36.78^{\circ} \mathrm{E}\right)$ is located about $50 \mathrm{~km}$ west of Moscow at Zvenigorod Scientific Station (ZSS) of the Institute.

The synchronous measurements at IAPh and ZSS were carried out firstly in July 2005. The continuous sodar measurements are set up at IAPh since 2005, at MSU since 2006 and at ZSS since 2008. In this study we use mostly the data obtained at IAPh and ZSS. These sites are located close enough to each other to be within the same meteorological system. On the other hand, IAPh is located well within the city and ZSS is far enough from it, so at ZSS the influence of the city can be neglected in the lower part of the ABL for any wind direction.

The three-axis Doppler sodars, type Latan-3 (Kouznetsov 2007), are used at all sites, having high noise immunity and are suitable for operation in noisy urban environments (Yushkov et al. 2007). During the measurements the sodars were operated at $1700 \mathrm{~Hz}$ carrier frequency with a $100 \mathrm{~ms}$ sounding pulse. The height resolution was set to $20 \mathrm{~m}$, while the effective sounding range was from $30 \mathrm{~m}$ to $200-500 \mathrm{~m}$ above ground (depends on the strati- 
fication of the $\mathrm{ABL}$ and ambient noise). The initial data on the three wind components along the sodar antenna axes were acquired every $15 \mathrm{~s}$. For this study the 30-min averaged data are used. The accuracy for the instantaneous values of Doppler velocities is about $0.3 \mathrm{~m} \mathrm{~s}^{-1}$, which results in a $0.1 \mathrm{~m}^{2} \mathrm{~s}^{-2}$ uncertainty of velocity variances. The accuracy of the averaged horizontal velocities is $0.5 \mathrm{~m} \mathrm{~s}^{-1}$. However, the difference between the velocities within the same profile is less, since the main source of the errors is the refraction of the sodar beam, which affects the measured values of velocity within the profile in the same way. We estimate this accuracy to be less than $0.1 \mathrm{~m} \mathrm{~s}^{-1}$. The measurements are timed in local daylight saving time (LDT), which is UTC +3 hours in winter and UTC +4 hours in summer.

The vertical structure of the thermal turbulence and the type of thermal stratification of the $\mathrm{ABL}$ were determined with sodar echograms, i.e. the return signal intensity plotted in heighttime coordinates. As an additional means to identify the thermal stratification, the vertical profiles of horizontal and vertical velocity components were used. There is no commonly accepted criterion to identify the LLJs. In this study we used a visual inspection of wind profiles in a similar manner to that done by Coulter (1981), Andreas et al. (2000) and Banta et al. (2002). The wind-speed profiles that have a local maximum exceeding by $1 \mathrm{~m} \mathrm{~s}^{-1}$ the wind speed above it were considered as jets. Note, that different threshold criteria can be found in the literature: $6 \mathrm{~m} \mathrm{~s}^{-1}$ (Bonner 1968), $2 \mathrm{~m} \mathrm{~s}^{-1}$ (Andreas et al. 2000; Baas et al. 2009), $0.5 \mathrm{~m} \mathrm{~s}^{-1}$ (Banta et al. 2002; Conangla and Cuxart 2006). The choice of the jet criterion in these studies substantially depended on the resolution of the equipment used. Also, criteria that are not based on the speed threshold were used in some studies (Kraus et al. 1985; Beyrich 1994). To characterize LLJs we used the following parameters: the jet-core height $Z_{\max }$, the jet maximum speed $V_{\max }$, the difference between the jet core speed and geostrophic wind speed $\Delta V_{\text {geo }}$, and the wind direction at the jet core. The statistical properties of LLJs were derived from hourly-averaged profiles. No additional selection of the data was made, thus the statistics represent the natural set of conditions for the region during the measurements.

The data on geostrophic winds were derived from the pressure fields of the operational forecasts of the European Centre for Medium-Range Weather Forecasts (ECMWF). The meteorological fields are stored in the archive with a time resolution of $3 \mathrm{~h}$, and data assimilation is performed every $12 \mathrm{~h}$. Thus the resulting fields are the analysis, and 3-, 6- and 9-h forecasts. The data on sea-level pressure of 0.15-degree resolution were interpolated around the location of the measurement site, where the horizontal pressure gradient was calculated.

\section{Nocturnal LLJs and the Geostrophic Wind}

To examine the predictions of the Blackadar model, we used the sodar measurements at ZSS during 27 days in July 2005. The close connection between the formation of the LLJ and the appearance of the nocturnal inversion is seen from matching the sodar echogram with wind-speed profiles (Fig. 3). A similar situation could be observed almost every summer night when the sky was clear. The distinguishable wind-speed maximum appeared about $2 \mathrm{~h}$ after the evening decay of thermal turbulence (around 2000 in Fig. 3).

The Blackadar model predicts the period of the oscillations $T=2 \pi / f$, where $f=$ $2 \Omega \sin \varphi$ is the Coriolis parameter, $\Omega$ is the angular speed of the Earth's rotation and $\varphi$ is latitude. At the latitude of Moscow $T \simeq 14 \mathrm{~h}$. The maximum wind speed in the jet core in most of the cases was recorded at 0300-0400 local time, i.e. $\simeq T / 2=7 \mathrm{~h}$ after the evening cessation of turbulence, which agrees with the model.

The inertial oscillations can be clearly seen in the hodographs of wind velocity at the jet height (Fig. 4). When the geostrophic wind does not vary strongly in time, the pattern is very 


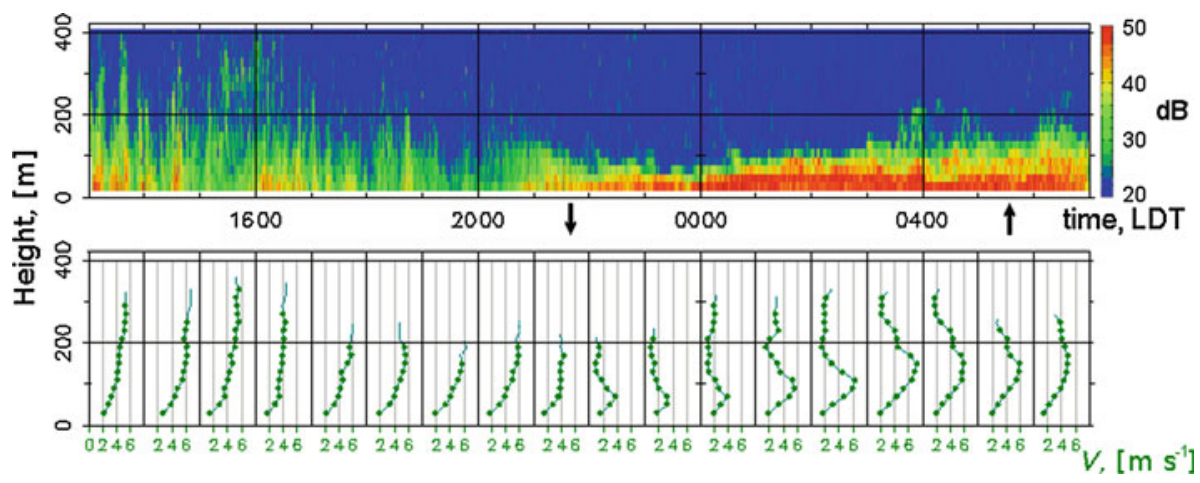

Fig. 3 The sodar echogram and corresponding wind-speed profiles showing the formation of the LLJ after the decay of turbulence near sunset. Sunset and sunrise are marked with arrows: ZSS 28-29 July 2005
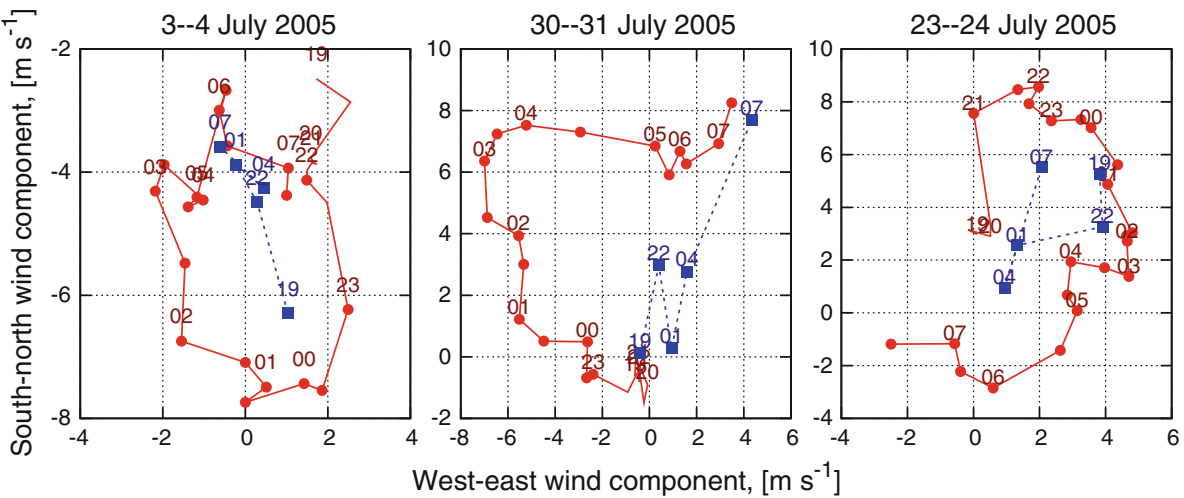

Fig. 4 The wind velocities at the jet-core height (red) and geostrophic velocities (blue) for three nights. The numbers at the points show corresponding local time (h). When no LLJ was detected the wind velocity at $80 \mathrm{~m}$ is taken, no bullet is shown for these points

similar to that predicted by the Blackadar model. For nine nights out of a total of 27 , the hodographs indicate the clear effect of the oscillations, and for four nights the oscillations could be recognised. In all cases of oscillation-like patterns the rotation occurs in the clockwise direction, which also agrees with the Blackadar model.

During nights when the oscillations were not seen in the hodographs, the pressure gradient and the geostrophic velocity varied significantly. Thus the variability of the pressure gradient is probably the main factor preventing the development of the oscillations. This agrees with the statement of Lundquist (2003), that the inertial oscillations are masked by other phenomena occurring at the same time (baroclinity, frontal passages, precipitation, etc.).

The Blackadar (1957) model also states that the jet-core height $Z_{\max }$ coincides with the height of the ground-based inversion $Z_{\text {inv }}$, which agrees with our data (Fig. 5a). Such a coincidence is due to the feedback that maintains the steady configuration of the ABL: when the inversion becomes higher, the turbulence production due to wind shear in the ABL decreases, preventing the elevation of the inversion beyond the equilibrium height, and vice versa.

Following Beyrich (1997) and Beyrich and Weill (1993) we have determined the inversion height from the vertical profile of the sodar return intensity, which is proportional to the 


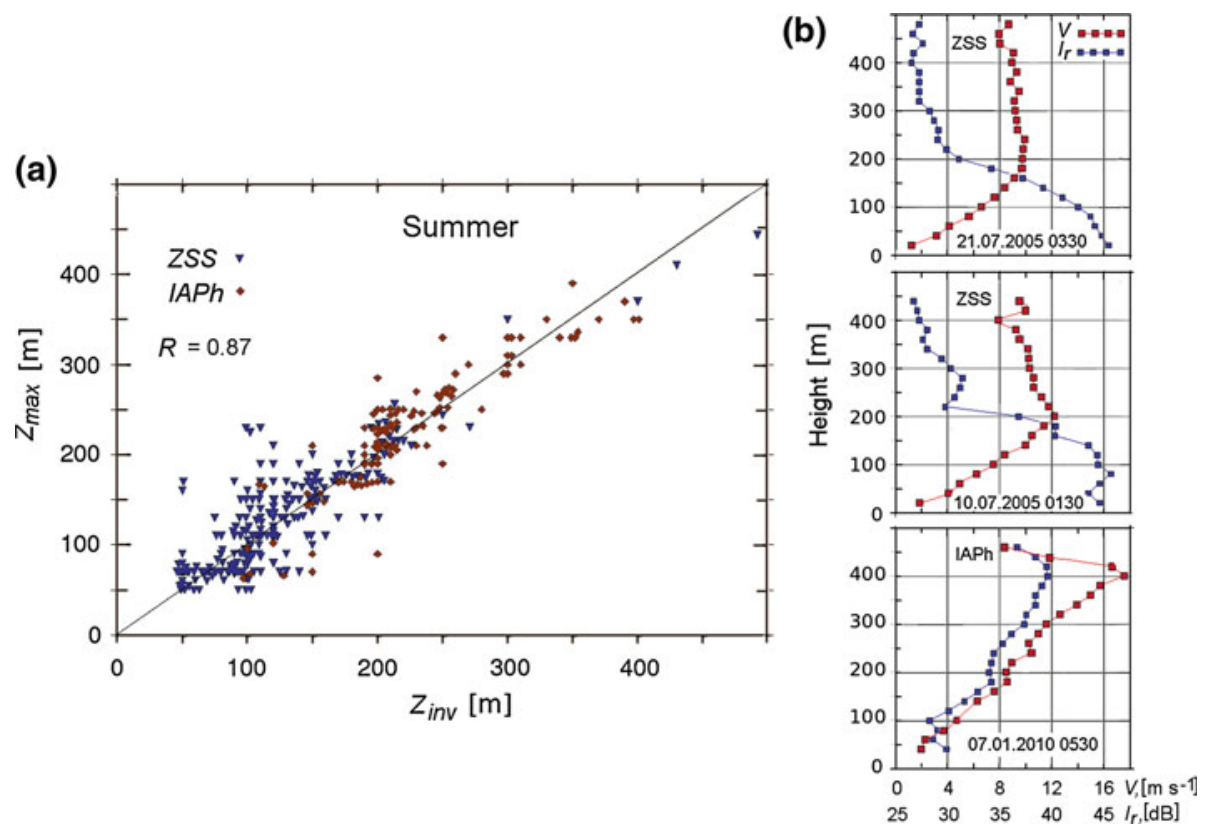

Fig. 5 The jet-core height $Z_{\max }$ versus the inversion height $Z_{\text {inv }}$ at the urban and rural sites in July 2005 (a). The examples of the echo-signal intensity profiles and corresponding wind-speed profiles in LLJ (b)

temperature structure parameter. The examples of the return-intensity profiles, together with wind-speed profiles, are given in Fig. $5 \mathrm{~b}$.

The problem of a connection between $Z_{\max }$ and $Z_{\text {inv }}$ has been discussed previously, and numerous experiments were performed to clarify this issue but the conclusions are contradictory (see e.g. Andreas et al. 2000; Milionis and Davies 2002). It is probably caused by poor accuracy in $Z_{\text {inv }}$ derived from the temperature profiles. The advantages of sodars among other means for determining $Z_{\text {inv }}$ were pointed out earlier by Arya (1981) and Garratt (1982). Though different points of the return intensity profile can be taken as $Z_{\text {inv }}$, in most cases the accuracy of the sodar is about 20-30 m (Beyrich and Weill 1993). This estimate agrees with the data of Balsley et al. (2006), who used a tethered balloon to measure the highresolution profiles of the wind speed, temperature, temperature structure parameter, and the kinetic energy dissipation rate. However, the upper boundaries of weak inversions are usually vague. For the case given in the top panel of (Fig. 5b) the uncertainty can be as large as $100 \mathrm{~m}$.

\section{The Influence of the Urban Environment on Nocturnal LLJs}

The simultaneous sodar measurements at the urban and rural sites revealed significant differences in the structure and evolution of the urban and rural ABL. The synchronous echograms (Fig. 6) clearly indicate the influence of the urban heat island (UHI) on the structure of the ABL. In the city the inversion layer is thicker and less variable during the nighttime, while the morning rise of the inversion layer is much less pronounced at the urban site.

The urban-rural difference shows up in wind speed-profiles as well. The jet core in the city is higher than at the rural site. The measurements of the jet profile below $120 \mathrm{~m}$ at the 

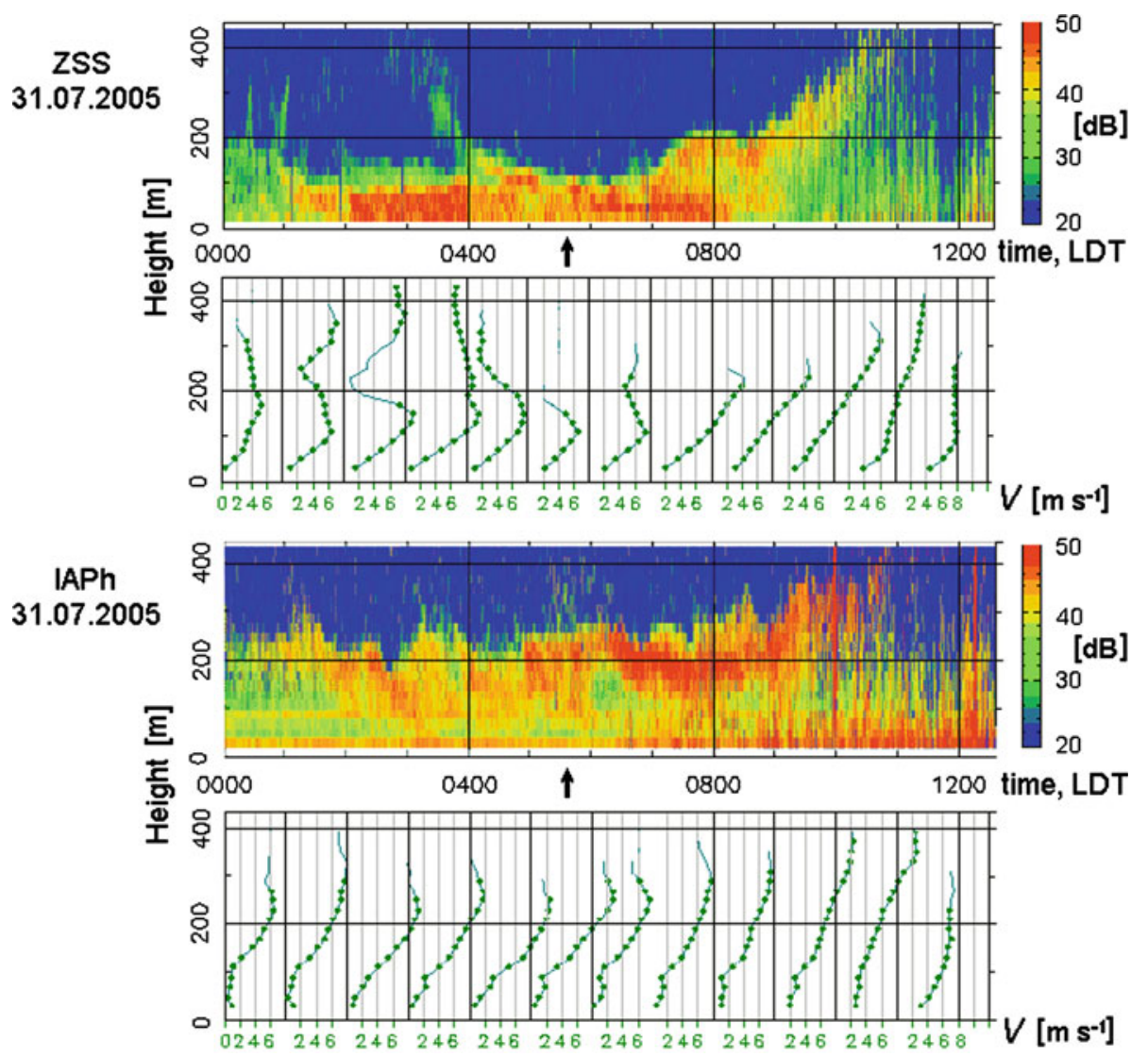

Fig. 6 The sodar echograms and hourly-averaged wind-speed profiles at rural (ZSS) and urban (IAPh) sites during the night of 31 July 2005

urban site are sometimes affected by ground clutter, which are hard to avoid in nocturnal sodar measurements in a built-up area. However, the shape of the wind profiles from above that height and the decreased return-signal intensity indicate the presence of a significant layer of smaller wind shear close to the ground. This layer appears due to the greater surface roughness and weaker cooling at the urban surface than in the surrounding rural area.

The influence of the urban surface on the nocturnal inversion has been observed earlier in many studies (e.g. Godowitch et al. 1985; Uno et al. 1988). A more detailed comparison of summertime nocturnal LLJs in urban and rural environment in Moscow region can be found in Kallistratova et al. (2009).

\section{The Long-Lived Wintertime LLJs}

Unlike in summertime, the wintertime ABL does not have such a strong diurnal variability, and thus LLJs have a much greater lifetime. The histograms of LLJ duration for urban and rural sites in summer and winter are shown in Fig. 7. We never observed summertime LLJs that lasted more than $13 \mathrm{~h}$, whereas the wintertime LLJs could last for four 
(a)

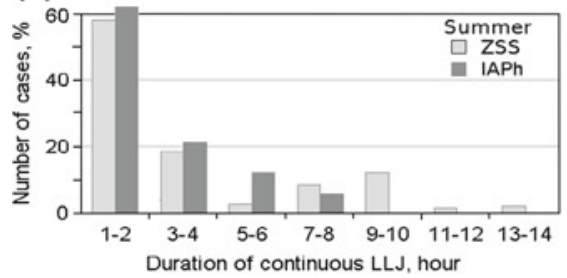

(b)

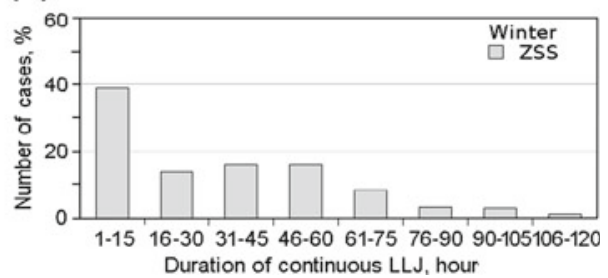

Fig. 7 The durations of LLJs in June 2005 (a) and in December 2009 (b) at the rural (ZSS) and urban (IAPh) sites

or more days. The maximum lifetime of the summertime LLJs in an urban area is much shorter than that in a rural area. The duration of the urban wintertime LLJs is not given in Fig. 7 because it was much shorter than the width of the first bar in the respective histogram.

Examples of sodar echograms and wind-speed charts (Fig. 8a, b) show typical temporal variability of the long-lived winter inversions. A layered structure of the echo-signal persists during the whole day. The inversion height varies during the day, the turbulent mixing also changes, but does not decay, so the LLJ persists. Figure 8c shows a similar plot for the summertime, when the diurnal change of the stratification type and evening decay of turbulence is clear.

Besides, Fig. 8 demonstrates shortcomings of the monostatic acoustic sounding. In the absence of residual turbulence, the height range is limited by the height of the radiative inversion, and does not allow for measurements of the wind speed in the upper part of the jet flow. Figure 9a shows the correlation between the jet-core height and the inversion height for urban and rural sites in wintertime. The scattering of points for wintertime is larger than in the similar plot for summertime (see Fig. 5), and, moreover, for the rural site the correlation coefficient $R$ is less than for the urban site. The reason probably relates to the larger fraction of weak inversions in wintertime, so the accuracy of the inversion height determination was lower. Overall, in wintertime, for long-lived LLJs the height of the inversion is also connected with the jet-core height.

The hodographs for wintertime jets have not revealed any clear evidence of inertial oscillations during two months in winter 2009-2010. Thus, the role of Coriolis forces and diurnal variations of the turbulent exchange coefficients in the formation and variability of the wintertime LLJ is not clear. The connection of the wind speed in the jet core with the geostrophic wind speed for wintertime is shown in Fig. 9b. On average, the wind speed in the jet core increases as the geostrophic wind increases although the correlation is poor. $V_{\max }$ exceeds $V_{\text {geo }}$ in about half of the cases.

The wintertime LLJs did not exhibit any directional preference, thus the effect of orography on their formation is small. Their long persistence indicates that their formation due to atmospheric fronts is also unlikely. A more realistic reason for their appearance is the combined effect of baroclinity, varying horizontal pressure gradient and variations in the layered structure of wintertime inversions, which could lead to different amplitudes and initial phases of oscillations in different layers. Due to the limitations of sodars we could not examine this hypothesis from our experiments. 

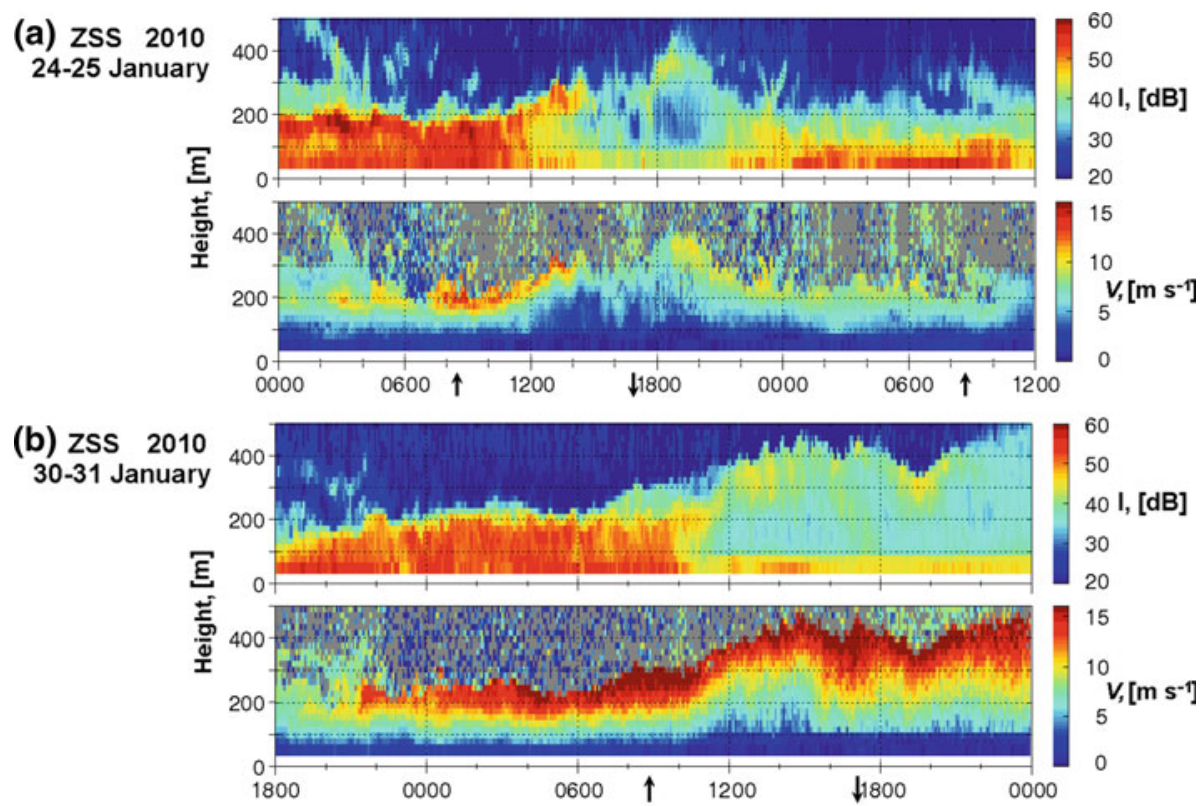

(c) ZsS 2005

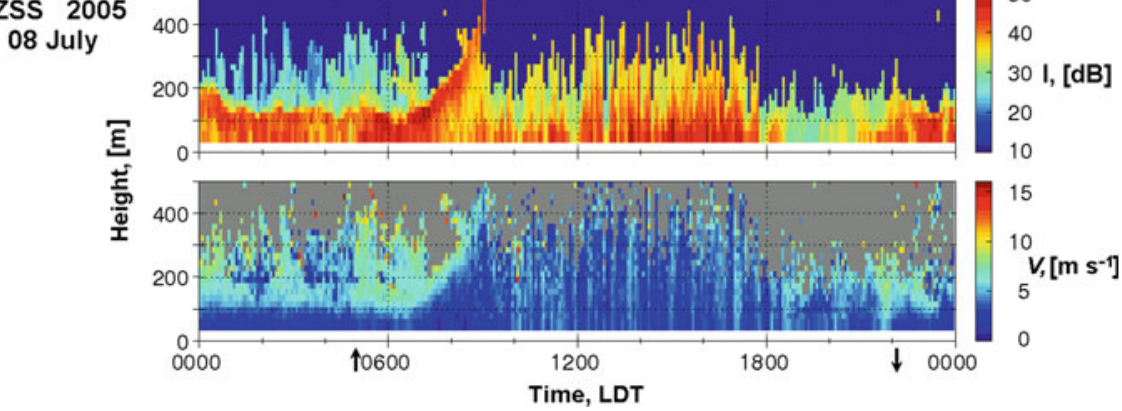

Fig. 8 The sodar echograms and wind-speed charts for long-lived wintertime inversions in the rural area (a and b, ZSS, January 2010); same for summertime (c, ZSS, July 2005)
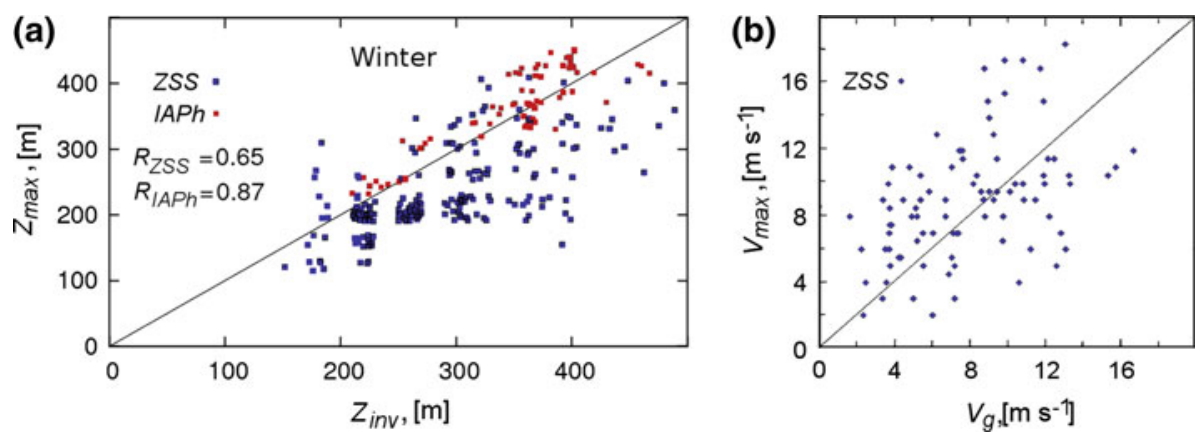

Fig. 9 The jet-core height versus the inversion height at rural (ZSS) and urban (IAPh) sites in January 2009 (a), and the wind speed in the jet core versus the geostrophic wind for rural (ZSS) site in January 2010 (b) 

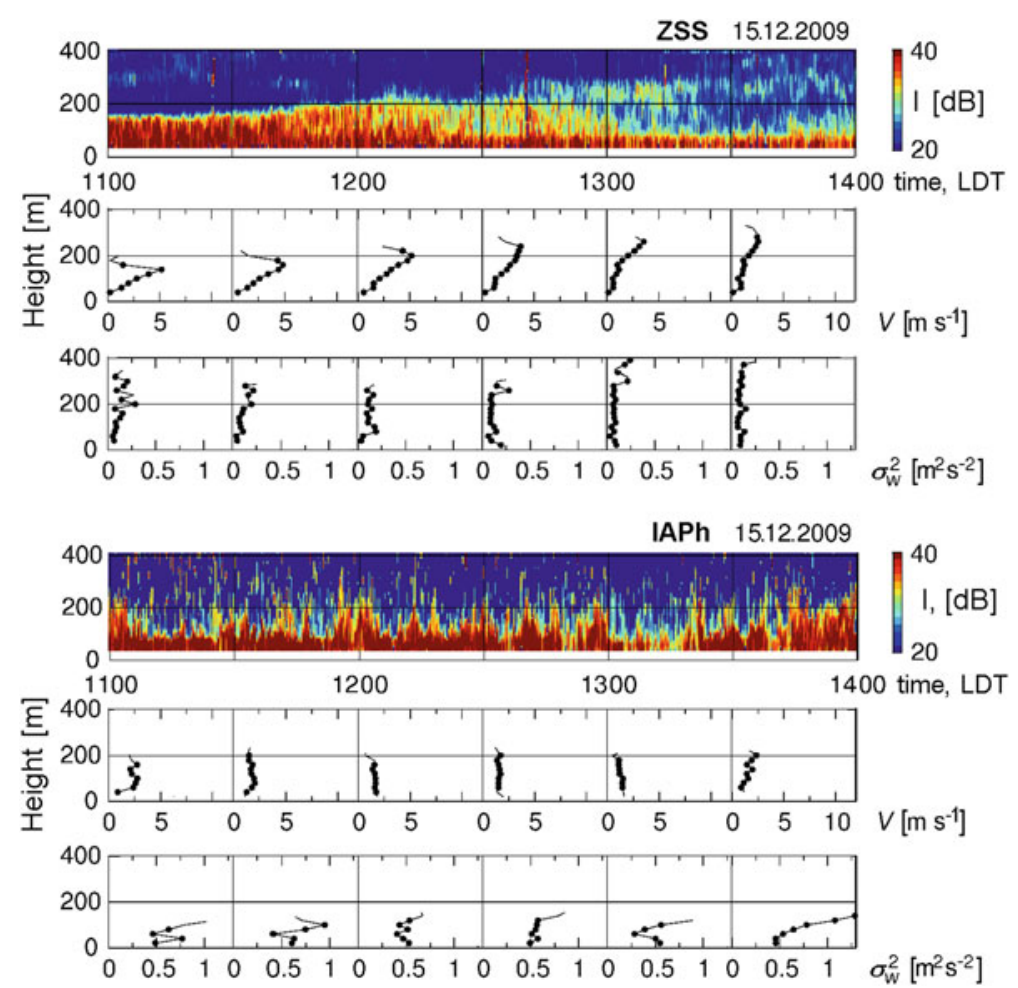

Fig. 10 Sodar echograms, wind-speed and vertical-velocity-variance profiles at urban (three upper panels) and rural (three lower panels) sites, 15 December 2009. $T=-22^{\circ} \mathrm{C}$

\section{The Influence of the Urban Heat Island on Wintertime ABL Stratification}

The LLJs are seldom formed over the city centre in wintertime. Synchronous echograms at IAPh and ZSS sites clearly show the effect of the UHI on the turbulent mixing in the wintertime ABL (Fig. 10). The urban echogram indicates well-developed convection, whereas at the rural site a temperature inversion and jet are observed.

In winter, at the rural site, the temperature inversions can last continuously for several days. Under very low temperatures, a long-lived convective layer forms over the Moscow city centre in the lower $400 \mathrm{~m}$. This convection is caused by the anthropogenic heat release by domestic heating, traffic, and electrical energy production. The convection has been regularly observed at the urban site during the cold winter of 2009-2010. At higher air temperatures $\left(>-5^{\circ} \mathrm{C}\right)$ the urban-rural difference was much less pronounced.

We have distinguished three types of urban-influenced wintertime boundary layer. The statistics of these types have been calculated for December 2009-January 2010 (total $1306 \mathrm{~h}$ of synchronous measurements). The developed convection in an urban environment with stable stratification of the rural ABL (Type 1) has been observed for $732 \mathrm{~h}$ ( $\simeq 55 \%$ of cases). This type occurs mostly when the air temperature is below $-8^{\circ} \mathrm{C}$, and the longest period of persistence of this type was about $120 \mathrm{~h}$. A Type 2 is characterized by a near-neutrally stratified urban boundary layer with stable rural ABL, and covers $150 \mathrm{~h}(\simeq 15 \%)$. Under cloudy 
Table 1 Mean vertical-speed variances $\sigma_{w}^{2}$ and corresponding eddy exchange coefficients $K_{\mathrm{T}}$ for the urban and the rural sites during December 2009

\begin{tabular}{llll}
\hline & Class 1 & Class 2 & Class 3 \\
\hline$\sigma_{w}^{2}$ (urban) $\left(\mathrm{m}^{2} \mathrm{~s}^{-2}\right)$ & 0.9 & 0.5 & 0.2 \\
$\sigma_{w}^{2}$ (rural) $\left(\mathrm{m}^{2} \mathrm{~s}^{-2}\right)$ & 0.1 & 0.1 & 0.2 \\
$K_{\mathrm{T}}$ (urban) $\left(\mathrm{m}^{2} \mathrm{~s}^{-1}\right)$ & 120 & 15 & 9 \\
$K_{\mathrm{T}}($ rural $)\left(\mathrm{m}^{2} \mathrm{~s}^{-1}\right)$ & 3 & 6 & 7 \\
\hline
\end{tabular}

The values of $\sigma_{w}^{2}$ and $\partial U / \partial z$ were averaged over the sodar range below $200 \mathrm{~m}$ a.s.l.

weather with strong winds near-neutral stratification at both sites occurs (Type 3), a period covers $409 \mathrm{~h}(\simeq 30 \%)$. The lack of joint data for eight days was caused by the malfunction of the sodars at one or both sites due to heavy snowfall.

The convection intensifies the mixing in the urban boundary layer. To evaluate the mixing intensity we estimated the turbulent exchange coefficient $K_{\mathrm{T}}$ using the approach developed by Kouznetsov et al. (2007), which utilizes the variance of the vertical wind component $\sigma_{\mathrm{w}}^{2}$ as a surrogate of the momentum flux:

$$
K_{\mathrm{T}} \simeq \frac{\sigma_{\mathrm{w}}^{2}}{\partial V / \partial z} .
$$

The estimated typical values of $K_{\mathrm{T}}$ in the ABL for three types of the urban-influenced wintertime boundary layer are summarized in Table 1, where it is clear that the values of $K_{\mathrm{T}}$ over the city significantly exceed those over the rural site. Note that the values in Table 1 were obtained by processing of a small part of the experimental data acquired, and therefore cannot be regarded as mean weather statistics.

It is generally accepted that the UHI negatively affects the comfort and health of the population. Different measures are undertaken all around the world to mitigate the UHI (see e.g. Rosenfeld et al. 1998; Corburn 2009). However, as is shown above, the UHI results in a significant increase in turbulent exchange in the urban ABL. Thus the UHI leads to the intensification of the removal of pollutants emitted close to the surface, from the lower part of the urban ABL. A similar positive effect of UHI has been recognized recently in Hong Kong (Yang and Li 2009).

\section{The Statistics of LLJs}

In this section we show the statistical parameters of LLJs above the Moscow city centre and above the nearby rural area for July 2005 and January 2009. The comparison of the appearance of LLJs at urban and at rural sites in summertime (July 2005) and wintertime (January 2009) is given in Table 2. In summertime the LLJs were observed at the rural site for most of the nocturnal hours, while at the urban site LLJs are less frequent. In wintertime, jets at the rural site were observed for more than half of the time, whereas only a few cases of urban LLJs were observed at the same time.

The time of appearance of LLJs during the day differs among the sites (Fig. 11a). In the rural area the number of LLJs is almost evenly distributed during the night: the LLJ emerges about $2 \mathrm{~h}$ before the sunset, and lasts till approximately $4 \mathrm{~h}$ after sunrise (in July sunset is about 2200 LDT and sunrise is about 0400 LDT). In the urban area, summertime LLJs 
Table 2 Number of hours of LLJs appearance for summertime and wintertime

For summertime only nocturnal hours (from 2100 till 0900 LDT) are accounted

\begin{tabular}{|c|c|c|c|c|}
\hline Total & At both sites & At ZSS only & At Moscow only & No LLJs \\
\hline \multicolumn{5}{|c|}{ Summertime, nocturnal } \\
\hline 324 & 84 & 134 & 40 & 66 \\
\hline $100 \%$ & $26 \%$ & $42 \%$ & $12 \%$ & $20 \%$ \\
\hline \multicolumn{5}{|c|}{ Wintertime } \\
\hline 744 & 71 & 348 & 12 & 313 \\
\hline $100 \%$ & $9 \%$ & $46 \%$ & $1 \%$ & $42 \%$ \\
\hline
\end{tabular}

(a)

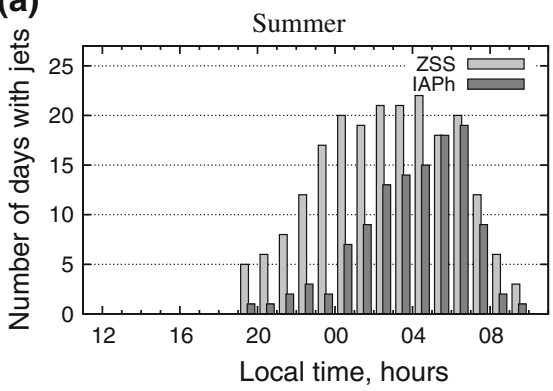

(b)

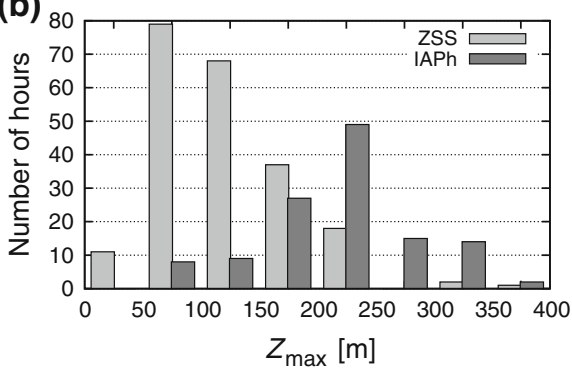

(c)

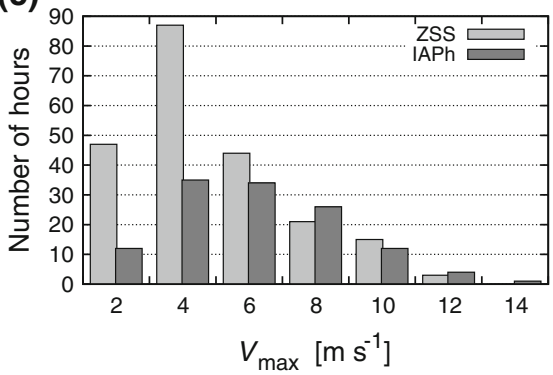

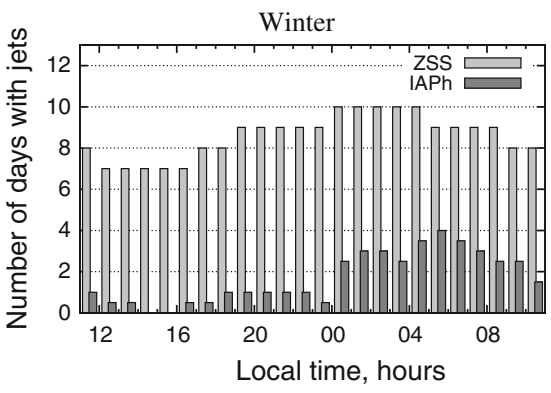
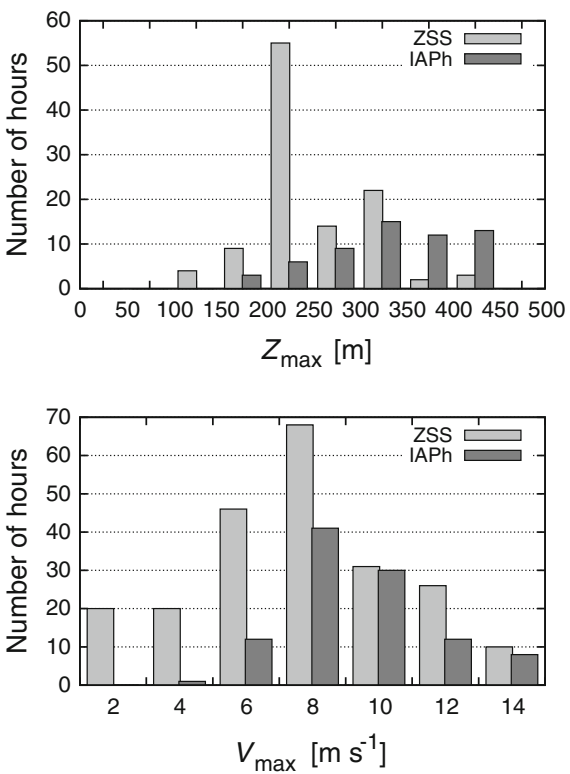

Fig. 11 The statistics of LLJs over the urban and rural sites for summertime (July 2005, left) and wintertime (January 2009, right). The diurnal appearance (a), and the distributions of jet-core height $Z_{\max }(\mathbf{b})$ and jet-core wind speed $V_{\max }(\mathbf{c})$

emerge much later, mostly after midnight and last for a shorter time. The wintertime LLJs are almost evenly distributed over the day in the rural area, whereas in the urban area they were observed mostly at night-time and early in the morning.

The jet core at the urban site is located higher than that at the rural site in both seasons (Fig. 11b). The urban surface prevents the formation of shallow inversions and associated 
LLJs, due to its higher roughness and weaker cooling. The reasons for the preferred height of the LLJ core at the rural site in wintertime are not clear.

The LLJ core speed is generally higher at the rural site (Fig. 11c), especially in winter. Thus, in the wintertime the effect of the urban boundary layer is greater. Strong LLJs ( $>6 \mathrm{~m} \mathrm{~s}^{-1}$ in summer and $>9 \mathrm{~m} \mathrm{~s}^{-1}$ in winter) appear over both sites with practically equal frequency.

The histograms shown in Fig. 11 are based on a small fraction of the data acquired and cannot be considered as climatological. However, they show several general features of LLJs in the Moscow region and their seasonal differences. The differences between LLJs in the urban and rural areas can be explained by the general difference in the ABL stratification due to the UHI effect. Since LLJs are closely related to the inversion layers, the difference between the summertime and wintertime LLJs also reflects the statistics of the inversion characteristics (see e.g. Pekour and Kallistratova 1993).

\section{Conclusions}

Despite several general limitations of a monostatic sodar, it is a convenient tool for longterm observations of LLJs and for the determination of their basic characteristics. The main advantage of a sodar is its ability to measure spatial and temporal features of LLJs and also to reveal the dynamics of the vertical structure of thermal turbulence in the ABL.

By means of a synchronous sodar measurements at two points, we have obtained the statistics of the main parameters of LLJs at urban and rural sites, including the first data on long-lived winter LLJs over land. The parameters of summertime nocturnal LLJs in a rural area agree with the Blackadar model for super-geostrophic jet flows. However, this model can hardly be applied to the long-lived wintertime LLJs when the diurnal variations of turbulent exchange are small. No clear inertial oscillation caused by the diurnal cycle on wintertime LLJs was detected. The effect of inertial oscillation caused by the variability of the turbulent viscosity within and above the inversion layer cannot be revealed with sodars due to their limited sounding range. Also, another mechanism (e.g. that proposed by Zilitinkevich et al. 1998 or by Chimonas 2005) could probably be responsible for the formation of wintertime LLJs. Since no clear reason for the appearance of long-lived wintry LLJs over homogeneous terrain is identified, further research is needed to reconfirm their existence from independent observations, and to develop relevant models for the phenomenon.

Both in summertime and in wintertime, the jet-core height is close to the height of the top of the ground-based or elevated inversion. This indicates the tight link between these two phenomena, so the emergence and properties of LLJs and temperature inversions have to be studied together.

Significant differences between the characteristics of summertime LLJs at urban and rural sites were found. The jets at the urban site appear more seldom, emerge later, are weaker and located higher than those at the rural site. These differences are likely caused by the storage heat and higher roughness of the urban surface, which influence the thermal structure of the urban ABL. The influence of the city on wintertime LLJs is even stronger. In winter, LLJs over the rural site are almost insensitive to the diurnal variations and can last for several days. In contrast, over the city the wintertime LLJs are observed rarely. Moreover, the radiative inversions practically are not formed over the urban site at low temperatures; instead, the convection emerges due to anthropogenic heat.

The variance of the vertical wind component above the city centre during the wintertime convection is often as large as in summer. During such convection, the turbulent mixing is at 
least an order of magnitude more intense than that observed at the rural site. This convection intensifies the removal of pollutants from the lower part of the urban ABL, and is obviously of great importance for the city and regional-scale air-quality modelling.

Acknowledgments We would like to thank Mr. D. D. Kouznetsov and Ms. M. A. Atletova from the Obukhov Institute of Atmospheric Physics for their help in the data processing, and Ms. J. Soares for helpful discussions. We also thank three anonymous reviewers for their comments on an earlier version of the manuscript. This work has been supported by the EC FP7 project ERC PBL-PMES (No. 227915), by Russian Foundation for Basic Research (Grants 08-05-00671 and 10-05-00802), by Academy of Finland (Project 139126) and by COST actions 728 and ES0602.

\section{References}

Anderson PS (2003) Fine-scale structure observed in a stable atmospheric boundary layer by sodar and kiteborne tethersonde. Boundary-Layer Meteorol 107:323-351

Andreas EL, Claffy KJ, Makshtas AP (2000) Low-level atmospheric jets and inversions over the western Weddell sea. Boundary-Layer Meteorol 97:459-486

Arya SPS (1981) Parameterizing the height of the stable atmospheric boundary layer. J Appl Meteorol 20(10):1192-1202. doi:10.1175/1520-0450(1981)020<1192:PTHOTS>2.0.CO;2

Baas P, Bosveld FC, Klein Baltink H, Holtslag AAM (2009) A climatology of nocturnal low-level jets at Cabauw. J Appl Meteorol Climatol 48(8):1627-1642. doi:10.1175/2009JAMC1965.1

Balsley BB, Frehlich RG, Jensen ML, Meillier Y (2006) High-resolution in situ profiling through the stable boundary layer: examination of the SBL top in terms of minimum shear, maximum stratification, and turbulence decrease. J Atmos Sci 63(4):1291-1307. doi:10.1175/JAS3671.1

Banta RM (2008) Stable-boundary-layer regimes from the perspective of the low-level jet. Acta Geophys 56:58-87. doi:10.2478/s11600-007-0049-8

Banta RM, Newsom RK, Lundquist JK, Pichugina YL, Coulter RL, Mahrt L (2002) Nocturnal low-level jet characteristics over Kansas during CASES-99. Boundary-Layer Meteorol 105:221-252

Beyrich F (1994) Sodar observations of the stable boundary layer height in relation to the nocturnal low-level jet. Meteorol Z 3:29-34

Beyrich F (1997) Mixing height estimation from sodar data-a critical discussion. Atmos Environ 31(23):3941-3953

Beyrich F, Weill A (1993) Some aspects of determining the stable boundary layer depth from sodar data. Boundary-Layer Meteorol 63:97-116. doi:10.1007/BF00705378

Blackadar AK (1957) Boundary layer wind maxima and their significance for the growth of nocturnal inversions. Bull Am Meteorol Soc 38:283-290

Bonner WD (1968) Climatology of the low level jet. Mon Weather Rev 96(12):833-850. doi:10.1175/ 1520-0493(1968)096<0833:COTLLJ $>2.0 . C O ; 2$

Brook RR (1985) The Koorin nocturnal low-level jet. Boundary-Layer Meteorol 32:133-154. doi:10.1007/ BF00120932

Brümmer B, Thiemann S (2002) The atmospheric boundary layer in an Arctic wintertime on-ice air flow. Boundary-Layer Meteorol 104:53-72

Byzova N (1982) Typical characteristics of the lowest 300-m atmospheric layer by measurements on highaltitude mast. Hydrometeoizdat, Moscow (in Russian)

Chimonas G (2005) The nighttime accelerations of the wind in the boundary layer. Boundary-Layer Meteorol 116:519-531. doi:10.1007/s10546-005-0609-x

Conangla L, Cuxart J (2006) On the turbulence in the upper part of the low-level jet: an experimental and numerical study. Boundary-Layer Meteorol 118:379-400. doi:10.1007/s10546-005-0608-y

Corburn J (2009) Cities, climate change and urban heat island mitigation: localising global environmental science. Urban Stud 46(2):413-427. doi:10.1177/0042098008099361

Coulter RL (1981) Nocturnal wind profile characteristics. In: Proceedings of the 1-st international symposium on acoustic remote sensing, Calgary, Canada, pp VI-1-VI-10

Coulter RL, Kallistratova MA (1999) The role of acoustic sounding in a high technology era. Meteorol Atmos Phys 71:3-13

Emeis S, Baumann-Stanzer K, Piringer M, Kallistratova M, Kouznetsov R, Yushkov V (2007) Wind and turbulence in the urban boundary layer-analysis from acoustic remote sensing data and fit to analytical relations. Meteorol Z 16(4):393-406 
Frehlich R, Meillier Y, Jensen ML, Balsley B, Sharman R (2006) Measurements of boundary layer profiles in an urban environment. J Appl Meteorol Climatal 45(6):821-837. doi:10.1175/JAM2368.1

Garratt JR (1982) Observations in the nocturnal boundary layer. Boundary-Layer Meteorol 22:21-48

Garratt JR (1985) The inland boundary layer at low latitudes. Boundary-Layer Meteorol 32:307-327

Godowitch JM, Ching JKS, Clarke JF (1985) Evolution of the nocturnal inversion layer at an urban and nonurban location. J Appl Meteorol 24:791-805. doi:10.1175/1520-0450(1985)024<0791:EOTNIL>2.0.CO; 2

Henderson GR, Leathers DJ (2010) European snow cover extent variability and associations with atmospheric forcings. Int J Climatol 30(10):1440-1451. doi:10.1002/joc.1990

Kallistratova MA (1994) Acoustic and radio-acoustic remote sensing study in CIS (former USSR). Int J Remote Sens 15(2):251-266

Kallistratova MA, Keder J, Petenko IV, Tieme NS (1985) Wind profile measurements by Doppler sounder in the stable and convective boundary layers. Izv Acad Sci USSR Atmos Ocean Phys 21:492-497

Kallistratova MA, Petenko IV, Shurygin EA (1987) Sodar study of wind field in the lower troposphere. Izv Acad Sci USSR Atmos Ocean Phys 23(5):451-462 (in Russian)

Kallistratova MA, Kouznetsov RD, Kuznetsov D, Kuznetsova I, Nakhaev M, Chirokova G (2009) The summertime low-level jet characteristics measured by sodars over rural and urban areas. Meteorol Z 18(3): 289-295

Karipot A, Leclerc MY, Zhang G (2009) Characteristics of nocturnal low-level jets observed in the north Florida area. Mon Weather Rev 137(8):2605-2621. doi:10.1175/2009MWR2705.1

King J, Lachlan-Cope T, Ladkin R, Weiss A (2008) Airborne measurements in the stable boundary layer over the Larsen Ice Shelf, Antarctica. Boundary-Layer Meteorol 127:413-428

Kouznetsov RD (2007) Latan-3 sodar for investigation of the atmospheric boundary layer. Atmos Ocean Opt 20(8):684-687

Kouznetsov RD, Kramar VF, Kallistratova MA (2007) The vertical structure of turbulent momentum flux in the lower part of the atmospheric boundary layer. Meteorol Z 16(4):367-373

Kraus H, Malcher J, Schaller E (1985) A nocturnal low level jet during PUKK. Boundary-Layer Meteorol 31:187-195

Lettau H (1990) The O'Neill experiment of 1953. Boundary-Layer Meteorol 50:1-9. doi:10.1007/ BF00120515

Lundquist JK (2003) Intermittent and elliptical inertial oscillations in the atmospheric boundary layer. J Atmos Sci 60(21):2661-2673. doi:10.1175/1520-0469(2003)060<2661:IAEIOI >2.0.CO;2

Mastrantonio G, Viola AP, Argentini S, Fiocco G, Giannini L, Rossini L, Abbate G, Ocone R, Casonato M (1994) Observations of sea breeze events in Rome and the surrounding area by a network of Doppler sodars. Boundary-Layer Meteorol 71:67-80

Milionis AE, Davies TD (2002) Associations between atmospheric temperature inversions and vertical wind profiles: a preliminary assessment. Meteorol Appl 9:223-228

Mitchell MJ, Arritt RW, Labas K (1995) A climatology of the warm season Great Plains low-level jet using wind profiler observations. Weather Forecast 10(3):576-591. doi:10.1175/1520-0434(1995)010<0576: ACOTWS $>2.0 . \mathrm{CO} ; 2$

Myagkov MS (2004) Urban heat budget and waste water heat discharge in Moscow. In: 5th AMS conference on urban environment, Vancouver, BC, p J2.7

Parish TR, Rodi AR, Clark RD (1988) A case study of the summertime Great Plains low level jet. Mon Weather Rev 116(1):94-105. doi:10.1175/1520-0493(1988)116<0094:ACSOTS >2.0.CO;2

Pekour MS, Kallistratova MA (1993) Sodar study of the boundary layer over Moscow for air-pollution application. Appl Phys B 57:49-55. doi:10.1007/BF00324100

Rosenfeld AH, Akbari H, Romm JJ, Pomerantz M (1998) Cool communities: strategies for heat island mitigation and smog reduction. Energy Build 28(1):51-62. doi:10.1016/S0378-7788(97)00063-7

Serreze MC, Schnell RC, Kahl JD (1992) Low-level temperature inversions of the Eurasian Arctic and comparisons with Soviet Drifting Station data. J Clim 5(6):615-629. doi:10.1175/1520-0442(1992)005<0615: LLTIOT>2.0.CO;2

Shapiro A, Fedorovich E (2010) Analytical description of a nocturnal low-level jet. Q J Roy Meteorol Soc 136:1255-1262. doi:10.1002/qj.628

Sjostedt DW, Sigmon JT, Colucci SJ (1990) The Carolina nocturnal low-level jet: synoptic climatology and a case study. Weather Forecast 5(3):404-415. doi:10.1175/1520-0434(1990)005<0404:TCNLLJ>2.0. $\mathrm{CO} ; 2$

Song J, Liao K, Coulter RL, Lesht BM (2005) Climatology of the low-level jet at the southern Great Plains atmospheric boundary layer experiments site. J Appl Meteorol 44(10):1593-1606. doi:10.1175/ JAM2294.1 
Tsvang LR, Zubkovskii SL, Kader BA, Kallistratova MA, Foken T, Gerstmann V, Przadka A, Pretel Y, Zeleny Y, Keder J (1985) International turbulence comparison experiment (ITCE-81). Boundary-Layer Meteorol 31:325-348

Uno I, Wakamatsu S, Ueda H, Nakamura A (1988) An observational study of the structure of the nocturnal urban boundary layer. Boundary-Layer Meteorol 45:59-82. doi:10.1007/BF00120815

Van de Wiel BJH, Moene AF, Steeneveld GJ, Baas P, Bosveld FC, Holtslag AAM (2010) A conceptual view on inertial oscillations and nocturnal low-level jets. J Atmos Sci 67(8):2679-2689. doi:10.1175/ 2010JAS3289.1

van Ulden AP, Wieringa J (1996) Atmospheric boundary layer research at Cabauw. Boundary-Layer Meteorol 78:39-69

Verghese SJ, Kizhakkemadam SN, Willitsford A, Collier JP, Unni S, Philbrick CR (2003) Characterization of nocturnal jets over Philadelphia during air pollution episodes using Radar/RASS and Raman lidar. In: Proceedings of the AMS 5th conference atmospheric chemistry, Long Beach, CA, p 6.10

Vihma T, Brümmer B (2002) Observations and modelling of the on-ice and off-ice air flow over the northern Baltic Sea. Boundary-Layer Meteorol 103:1-27

Vihma T, Lüpkes C, Hartmann J, Savijärvi H (2005) Observations and modelling of cold-air advection over Arctic sea ice. Boundary-Layer Meteorol 117:275-300

Wang Y, Klipp CL, Garvey DM, Ligon DA, Williamson CC, Chang SS, Newsom RK, Calhoun R (2007) Nocturnal low-level-jet-dominated atmospheric boundary layer observed by a Doppler lidar over Oklahoma city during JU2003. J Appl Meteorol Climatol 46:2098-2109

Whiteman CD, Bian X, Zhong S (1997) Low-level jet climatology from enhanced rawinsonde observations at a site in the southern Great Plains. J Appl Meteorol 36(10):1363-1376. doi:10.1175/ 1520-0450(1997)036<1363:LLJCFE > 2.0.CO;2

Yang L, Li Y (2009) Ventilation potential by thermal buoyancy in an urban city: numerical simulation and field experiment study. In: Proceedings 7-th international conference on urban climate, Yokohama, Japan, Paper No. A6-6

Yushkov VP, Kallistratova MA, Kouznetsov RD, Kurbatov GA, Kramar VF (2007) Experience in measuring the wind-velocity profile in an urban environment with a Doppler sodar. Izv Atmos Ocean Phys 43:168-180. doi:10.1134/S0001433807020041

Zhong S, Fast JD, Bian X (1996) A case study of the Great Plains low-level jet using wind profiler network data and a high-resolution mesoscale model. Mon Weather Rev 124(5):785-806. doi:10.1175/ 1520-0493(1996)124<0785:ACSOTG>2.0.CO;2

Zilitinkevich S, Johansson P-E, Mironov DV, Baklanov A (1998) A similarity-theory model for wind profile and resistance law in stably stratified planetary boundary layers. J Wind Eng Ind Aerodyn 74-76:209-218. doi:10.1016/S0167-6105(98)00018-X 